\title{
Intellectual Freedom? Censorship in North Carolina, 1981-1985
}

\section{From the pages of North Carolina Libraries}

by Barbara A. Thorson

v.44, no. 4 (Winter 1986), pp. 230-232

\section{$\mathrm{T}$} The 1960's was known for demonstrations on college camsocial issues led to attempts to restrict speech. Intellectual freedom was not an issue.

The 1980's have brought a new emphasis on intellectual freedom. Censorship attempts have been made both in educational and non-educational institutions. The purpose of this article is to present a brief overview of censorship from 1981 to May 1985 in North Carolina. In the 1980's, endeavors by a variety of groups brought censorship to a peak. The information is based on reported incidents to the American Library Association's Office of Intellectual Freedom and published in the Newsletter on Intellectual Freedom. This article includes statistics regarding the annual number of cases, location of attempts, sources or initiators of attempts, reasons, affected institutions, the objects of the censored attempts and the outcome for libraries.

Table 1: Number of reported cases

\begin{tabular}{|c|c|c|}
\hline 1981 & & 7 \\
\hline 1982 & & 6 \\
\hline 1983 & & 0 \\
\hline 1984 & & 0 \\
\hline 1985 & & 2 \\
\hline & Total & 15 \\
\hline
\end{tabular}

Between 1966 and 1980, twenty-five cases in North Carolina were reported to ALA. Of the twenty-five, six were reported in $1980 .{ }^{1}$ From January 1981 to May 1985, fifteen cases were reported. (see Table 1) Eighty-seven per cent of the total number of incidents occurred during 1981 and 1982. In 1981 the Moral Majority launched a state-wide campaign in North Carolina to target and remove materials deemed unfit. ${ }^{2}$

A survey conducted in 1983 by North Carolina People for the American Way reported 243 censorship attempts since $1980 .^{3}$ This information was collected by distributing questionnaires to public school educators. North Carolina People's survey could account for the lack of reports to ALA during 1983 and 1984.

Barbara A. Thorson is media coordinator at Union Grove Elementary School, Union Grove, N.C.

230 - North Carolina Libraries

Table 2: Locations of Censorship Attempts

\begin{tabular}{|l|l}
\hline Buncombe County & 2
\end{tabular}

Charlotte 1

\begin{tabular}{l|l}
\hline Farmville & 1
\end{tabular}

Gastonia 1

\begin{tabular}{l|l} 
Haywood County & 1
\end{tabular}

Lincolnton 1

\begin{tabular}{|l|l} 
Mars Hill & 1
\end{tabular}

New Hanover County 1

\begin{tabular}{l|l} 
Raleigh & 2 \\
\hline
\end{tabular}

$\begin{array}{ll}\text { Statesville } & 1\end{array}$

Troutman

Winston-Salem

1

The majority of endeavors was aimed at public schools. While the survey included all areas of the state, including large and small towns, smaller rural areas were predominant. (see Table 2) Unlike previous reports, the only postsecondary town was the rural town of Mars Hill. The two attempts in Winston-Salem were at the public library.

Table 3: Sources of Attempts

\begin{tabular}{|l|l|}
\hline Citizen & 4 \\
\hline Student & 1 \\
\hline Parents & 7 \\
\hline County Commissioner & 1 \\
\hline College Coach & 1 \\
\hline Unknown & 1 \\
\hline Principal & 1 \\
\hline
\end{tabular}

Parents were the primary source of censorship attempts, and earlier research reflects this fact. (see Table III) Five of the seven attempts by parents were from rural areas. Two of the cases were in Iredell County. Run Shelley Run was removed from the middle school but was considered appropriate for the high school level. ${ }^{4}$ Having been presented with a vast amount of information and numerous book reviews, the Ire-dell County Board of Education placed Huxley's Brave New World back in the classrooms. ${ }^{5}$

Another case involved the principal of a church school, and he opposed The Living Bible because the book had been criticized by fundamentalists as being a "dangerous corruption" of God's word.

Citizens' attempts at censorship were usually initiated without group 
pressure, but one instance concerned a group of school district residents led by several fundamentalist ministers who questioned the school's selection policy. ${ }^{7}$ Specific titles were not protested but works such as The Grapes of Wrath and Andersonville were indicated as being "indecent".

Table 4: Reasons for Censoring

\begin{tabular}{|l|l|}
\hline Language & 4 \\
\hline Pornography & 2 \\
\hline Sex & 3 \\
\hline Nudity & 2 \\
\hline Immorality & 1 \\
\hline Religion & 1 \\
\hline Perverted & 1 \\
\hline Wickedness & 1 \\
\hline Indecency & 1 \\
\hline Illustrations & 1 \\
\hline Values in classroom & 1 \\
\hline Criticism of Organization & 1 \\
\hline
\end{tabular}

The total number of reasons exceeds the number of attempts because it is hard to categorize cases, and often more than one reason was given. Although most of the causes in the broad range of reasons could be categorized neatly, others were a matter of interpretation. (see Table 4) Several categories are closely related: language, pornography and sex, but such terms as "immoral" could refer to sex or pornography.

Parents were the primary source of censorship attempts.

"Rough language" was given as a reason to remove It's OK if You Don't Love $M e{ }^{8}$ The decision to purchase the book was made from past experiences with Norma Klein's works. The decision by the board was unanimous to remove the book. A parent and a local minister in Farmville questioned the "objectionable language" in The Catcher in the Rye; however, on the basis of parental approval, the board voted to retain the book.
Table 5: Institutions Affected

\begin{tabular}{|l|l|}
\hline Public Library & 3 \\
\hline Elementary/Middle School & 6 \\
\hline High School & 4 \\
\hline College/University & 1 \\
\hline Christian School & 1 \\
\hline
\end{tabular}

Compared to the previous research by Woods, there was a shift in institutions affected by censorship attempts. In the above-mentioned research, $48 \%$ of all the attempts were made at the high school level. ${ }^{10}$ Of those cases reported to ALA between 1981 and 1985, 26\% were in high schools, and $40 \%$ occurred at the elementary and middle school level. Compared to six cases prior to 1981 , only one college, in a small town, appeared in the report. In his editorial, the athletic trainer who was also the editor of the school paper "blasted"11 the head coach for criticizing the football team. The coach fired the trainer for his comments.

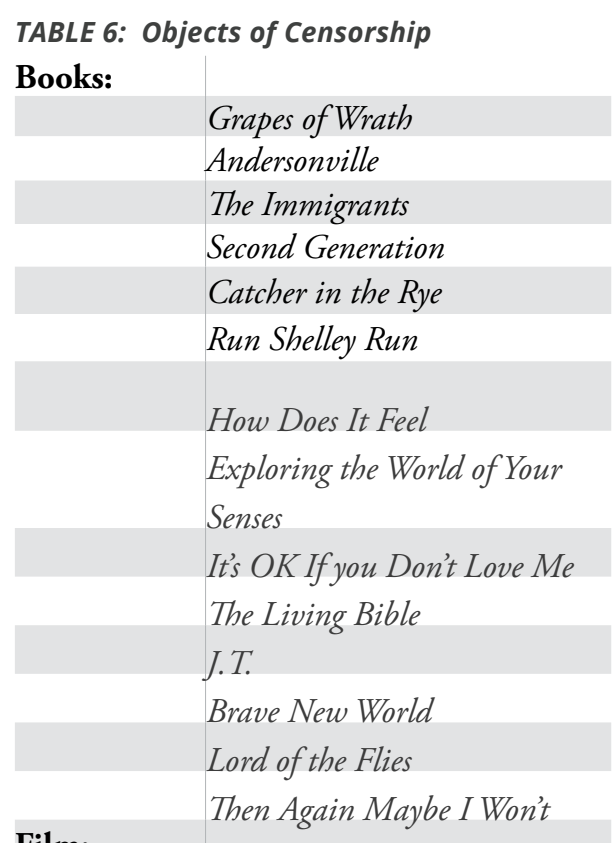

Film:

Newspaper:

LaCage Aux Folles

\begin{tabular}{l|l} 
& Hilltop (college newspaper) \\
Magazine: & \\
& Playboy
\end{tabular}

Books headed the list of censored material. As expected classics were among the most frequently censored titles. Andersonville and Catcher in the Rye appeared in earlier research also. There were no reported attempts on textbooks, and one film was censored by a county commissioner. La Cage Aux Folles, the French version of Birds of a Feather, was not shown at the Forsyth County Library because it was not "appropriate for general audiences," but Sister Michele Powell, a Catholic nun and Christian counselor, said she felt "mature enough to decide whether to do something" (watch the film). ${ }^{12}$ Also at Forsyth County Library, a parent, concerned that his daughter might be exposed to dirty pictures, objected to the presence of Playboy. ${ }^{13}$ The various censored materials had no similarities to one another.

\section{Table 7: Disposition of Attempts}

\begin{tabular}{|l|l|}
\hline Successful & 4 \\
\hline Partially successful & 2 \\
\hline Unsuccessful & 6 \\
\hline Unknown & 3 \\
\hline
\end{tabular}

The figures in Table 7 indicate a shift from Wood's report. ${ }^{14}$ Wood's research revealed $64 \%$ of all censorship cases were successful or partially successful and $24 \%$ were unsuccessful. Since 1981 only $40 \%$ of the cases reported to ALA were successful or partially successful and $40 \%$ were unsuccessful. The number of "unsuccessful" cases has increased.

A censored attempt achieved with or without judicial or court action is considered "successful". A "partially successful" attempt is one that is compromised from the original intent of the censor. As an example of the latter, the books The Immigrants and Second Generation were first removed from a school library but later made available to students with parental permission. ${ }^{15}$ While this will limit access to the titles 
the compromise will allow the books to remain in the library.

No doubt many of the individuals and groups feel it is their duty to censor materials they consider unsuitable.
Since North Carolina is located in the "Bible Belt" and is a target for groups such as the Moral Majority, librarians and citizens need to keep abreast of activities aimed at diminishing

\section{References}

${ }^{1}$ L.B. Woods and Alesandra M. Schmidt, "'First in Freedom? Censorship in North Carolina, 1966-1980," North Carolina Libraries, 41, no. 1 (Spring 1983): 23.

2 Newsletter on Intellectual Freedom 30 (March 1981): 1.

3 Ibid. 53 (January 1984): 3.

${ }^{4}$ Newsletter 31 (March 1982): 45.

5 Newsletter 30 (March 1981): 48.

${ }^{6}$ Newsletter 30 (July 1981): 105.

7 Newsletter 30 (May 1981): 74.

${ }^{8}$ Newsletter 31 (March 1982): 44.

${ }^{9}$ Newsletter 31 (March 1982): 58.

${ }^{10}$ Woods, 25.

${ }^{11}$ Newsletter 31 (March 1982): 50.

${ }^{12}$ Newsletter 30 (March 1981): 40.

${ }^{13}$ Newsletter 34 (March 1985): 59.

${ }^{14}$ Woods, 26.

${ }^{15}$ Newsletter 31 (November 1982): 158.

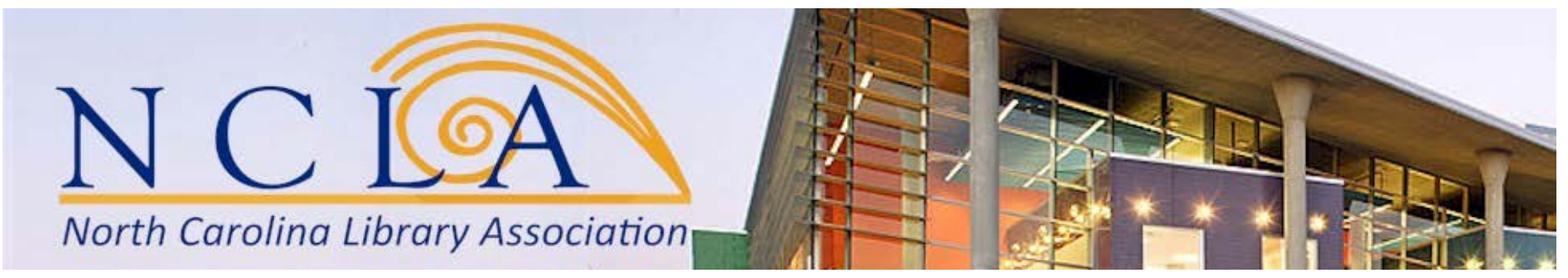
http://www.nclaonline.org/ 